\title{
SYNTHESIS AND CHARACTERIZATION OF NEW AZO-SCHIFF BASES AND THEIR BIOLOGICAL ACTIVITY
}

\author{
Hamid Hussein Eissa \\ Chemistry Department, Applied College Sciences, University of Hajah, Yemen \\ Email: hamedesia2003@yahoo.com
}

\begin{abstract}
This work focused on the synthesis of new azo Schiff bases which were prepared by condensation of 3-formyl-4-hydroxy phenylazo benzene with both 1,3-diamino xylylene, 2,6-diamino Pyridine, 1,5-diamino-2-methyl pentane respectively. The Schiff bases were checked by different spectral technique (LC-MS, GC-MS, 1H-NMR, IR). The new azo Schiff Bases were studied for antibacterial activities against (Bacillus subtilis and Staphylococcus aureus) are Gram positive and (Salmonella typhi and Escherichia coli) is Gram negative. The azo compound ligand were exhibited a vari-able activity of inhibition on the growth of the bacteria.
\end{abstract}

Keywords: Azo Schiff base, 3-Formyl-4-Hydroxy Phenylazo Benzene, Spectral Technique, Anti-Microbial Activity.

\section{INTRODUCTION}

Schiff bases are compounds which prepared by the condensation of aldehyde or ketone with primary amines [1-3]. Schiff bases are used in the synthesis of some industrial, bioactive and inorganic compounds [4-5]. The compounds include good fungicdal activity [6], Anticancer [7-9], antibacterial [10-12], antifungal $[13,14]$, antiinflammatory [15-17] and herbicidal activities[18]. Azo compounds are widely used as dyes and pigments. Another application is analytical chemistry. On the other hand azo compounds show biological activities [18]. Schiff bases and azo compounds are important structures in the medicinal and pharmaceutical fields [19]. Azo compounds, with two phenyl rings separated by an azo $(-\mathrm{N}=\mathrm{N}-)$ bond, are versatile molecules and have received much attention in research areas both fundamental and application [20]. The strong electronic absorption maximum can be tailored by ring substitution to fall anywhere from the ultraviolet to red-visible regions, allowing chemical fine-tuning of colour [20]. This, combined with the fact that these azo groups are relatively robust and chemically stable, has prompted extensive study of azo benzenebased structures as dyes and colorants. Furthermore, the light-induced inter conversion allows systems incorporating azo group to be used as photo switches, effecting rapid and reversible control over a variety of chemical, mechanical, electronic and optical properties [21].

Recently heterocyclic azo compounds have been used in the Mitsunobu reaction [22]. Usually, azo compounds were synthesized by diazoti-zation of the amine in mineral acid at about $0^{\circ} \mathrm{C}$ [22-26]. Schiff bases are used as substrates in the preparation of a large amount of bioactive and industrial compounds [27-31]. Azo compounds have a 
great biological activity as well as industrial importance $[32,33]$. The interaction of metal complexes with biological systems, which is the field of bio coordination chemistry, is receiving an increasing interest [34]. In this study new Schiff base of 3-formyl-4-hydroxy phenylazo benzene with 1,5-diamino -2 methyl pentane,1,3-diamino xylene and 2,6diamino Pyridine were prepared and subjected to antimicrobial activity against different gram-positive and gram-negative bacteria.

\section{EXPERIMENTAL}

\subsection{MATERIALS AND METHODS}

Ethanol, dimethyl formamide, salicylaldehyde, aniline, 1,3-diamino xylylene, 2,6diamino Pyridine, 1,5-diamino-2-methyl pentane, Nutrient gar, Filter paper discs (Whatman No.1 filter paper, $5 \mathrm{~mm}$ diameter). All materials obtained from Sigma Aldrich Company. IR spectra were recorded on Jasco 300 FT-IR spectrometer using compressed $\mathrm{KBr}$ discs. Mass spectra of the compounds were measured on a micro mass Quattro LCMS/MS, GC-MS/MS Spectrometer. 1HNMR spectra were recorded at ambient Bruker DT-400 Spectrometer using $\mathrm{CDCl}_{3}$ with DMSO- DMF as the internal standard, M.P Apparatus Digital $\left(32-300{ }^{\circ} \mathrm{C}\right)$.

\subsubsection{Synthesis of 3-formyl-4-hydroxy phenylazo benzene}

Azoaldehyde was prepared from aniline and 2-hydroxy benzaldehyde in aqueous medium at $0-5{ }^{\circ} \mathrm{C}$ according to a reported method and was purified by recrystallization from warm 95\% ethanol [35].

\subsubsection{Synthesis of Bis-N-(5-phenylazo-2-hydroxy-} 1-benzylidine)-1,3-diamino xylylene (I)

A hot ethanolic solution ( $40 \mathrm{ml})$ of 3-formyl 4-hydroxy phenylazo benzene $(2.26 \mathrm{~g}-0.01$

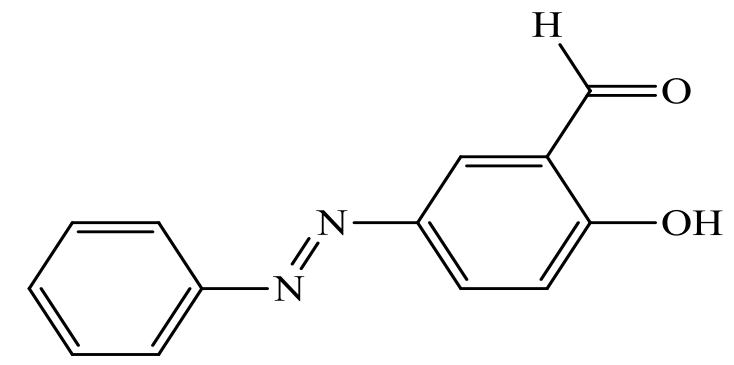

Scheme 13 -formyl-4-hydroxy phenylazo benzene

mol) was added to a hot ethanolic solution $(40 \mathrm{ml})$ of 1,3 -diamino xylylene. $(0.68 \mathrm{~g}$ $0.005 \mathrm{~mol}$ ) and the reaction mixture was refluxed for 3 hour. A solid mass (Scheme 2) seprated out on cooling [36, 37]. It was suction filtered, washed with ethanol, diethyl ether and recrystallized from suitable solvent, then dried in vacuum.

Orange; Yield: $(80 \%), \mathrm{m} . \mathrm{p}=189.3-189.6{ }^{\circ} \mathrm{C}$, Empirical formula: $\quad\left(\mathrm{C}_{34} \mathrm{H}_{28} \mathrm{~N}_{6} \mathrm{O}_{2}\right)$, M.Wt: 552.

Mass spectrum (m/z):552. (Fig.1.)

UV-Vis: $\lambda \max =355 \mathrm{~nm}$ (Fig.2.)

IR (KBr disk): $3417.86-3468.01 \mathrm{~cm}^{-1}(\mathrm{O}-\mathrm{H})$, 3008.95-3062.96 $\mathrm{cm}^{-1}$ (C-H, aromatic), $2881.65 \mathrm{~cm}^{-1}$ (C-H, aliphatic), $1631.78 \mathrm{~cm}^{-1}$ $(\mathrm{C}=\mathrm{N}), \quad 1585.49 \mathrm{~cm}^{-1} \quad(\mathrm{C}=\mathrm{C}$, aromatic $)$, $1489.05 \mathrm{~cm}^{-1}(-\mathrm{N}=\mathrm{N}-), 1284.59 \mathrm{~cm}^{-1}$ (C-O, phenolic) (Fig.3.)

$1 \mathrm{H}-\mathrm{NMR}\left(\mathrm{CDCl}_{3}-400 \mathrm{MHz}\right) \delta=14(\mathrm{~s}, 2 \mathrm{H}$, $\mathrm{OH}), 8.584(\mathrm{~s}, 2 \mathrm{H}, \mathrm{CH}=\mathrm{N}), 7.085-8.023$

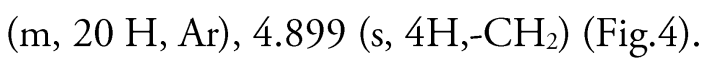

Elemental analysis: $\mathrm{C}_{34} \mathrm{H}_{26} \mathrm{~N}_{8} \mathrm{O}_{4}$, Calculated (\%) C: 73.90; H: 5.11; N: 15.21 Found (\%) C: 73.97, H: 5.17, N: 15.18 .

\subsubsection{SYNTHESIS OF BIS-N-(5-PHENYLAZO-2- HYDROXY-1-BENZYLIDINE) - 2,6-DIAMINO PyRIDINE. (II) SCHEME (3)}

Azo-coupled precursors were prepared as described previously [35] was added (0.01 mol) of 3-formyl-4-hydroxy phenylazo benzene in $30 \mathrm{ml}$ from absolute ethanol to 2,6-diamino Pyridine, $(0.005 \mathrm{~mol})$ in $60 \mathrm{ml}$ ethanol. The reaction mixture was refluxed 


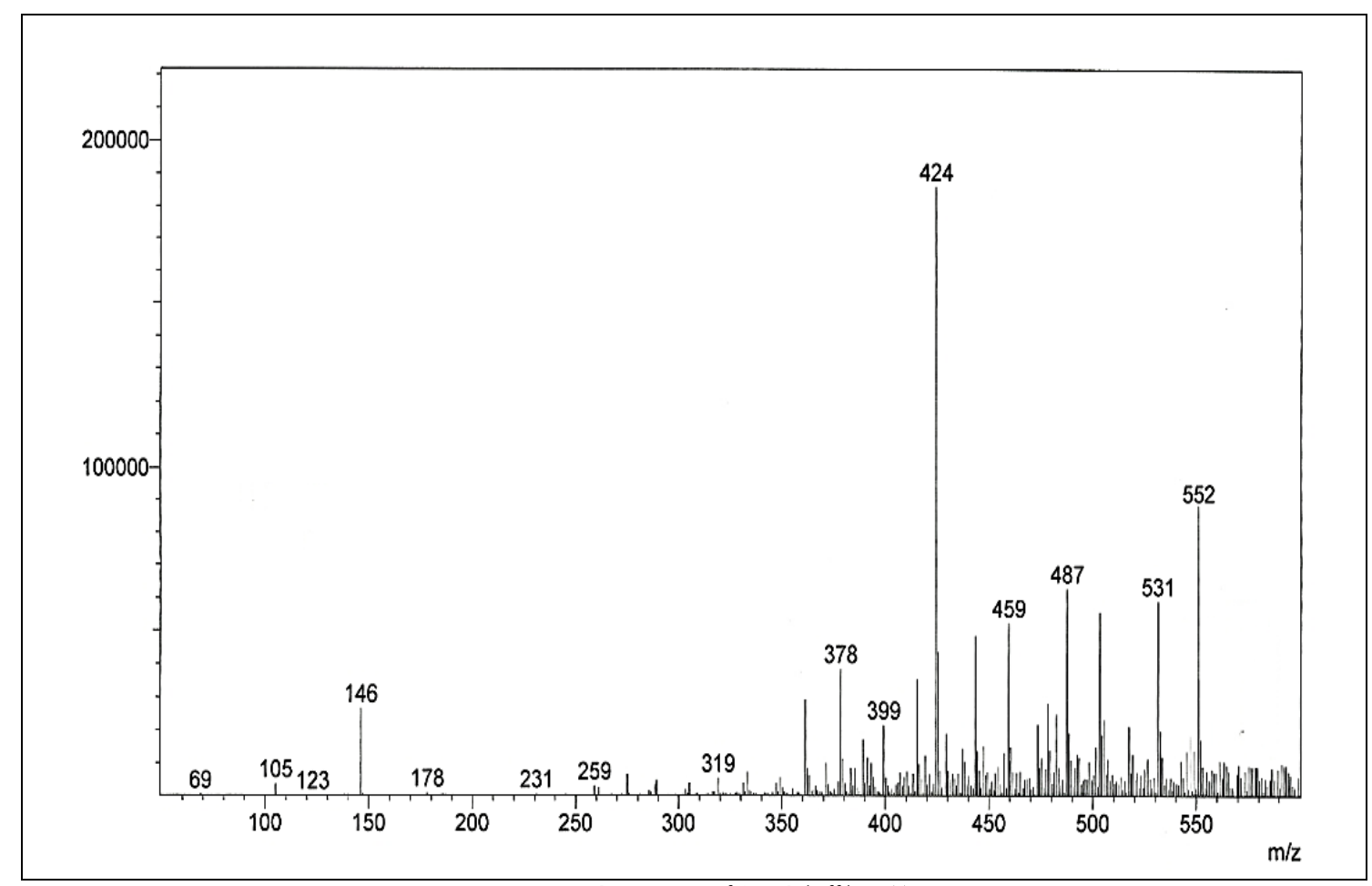

Fig.1. MS spectrum of Azo-Schiff base(I)

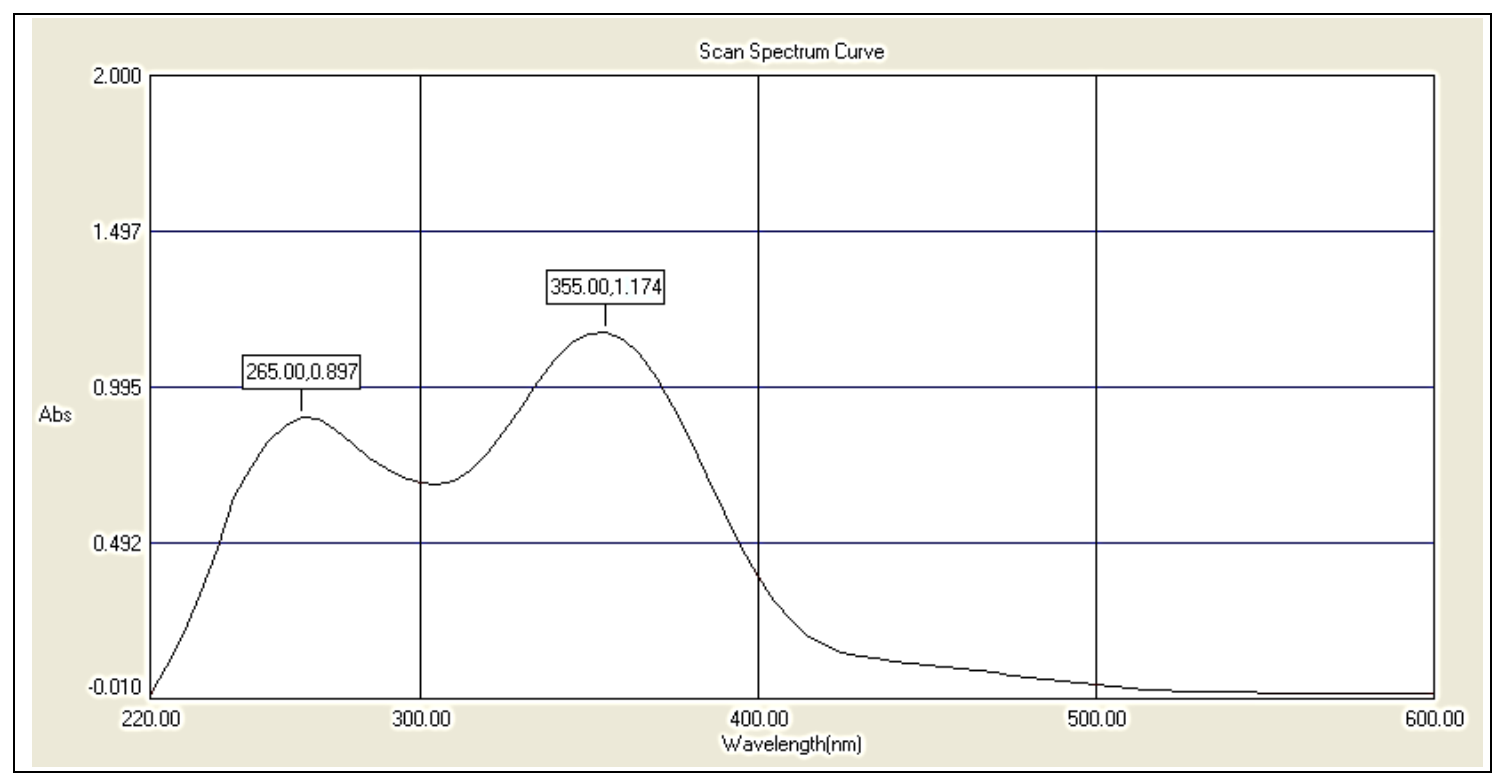

Fig.2. UV spectrum of Azo Schiff base(I) 


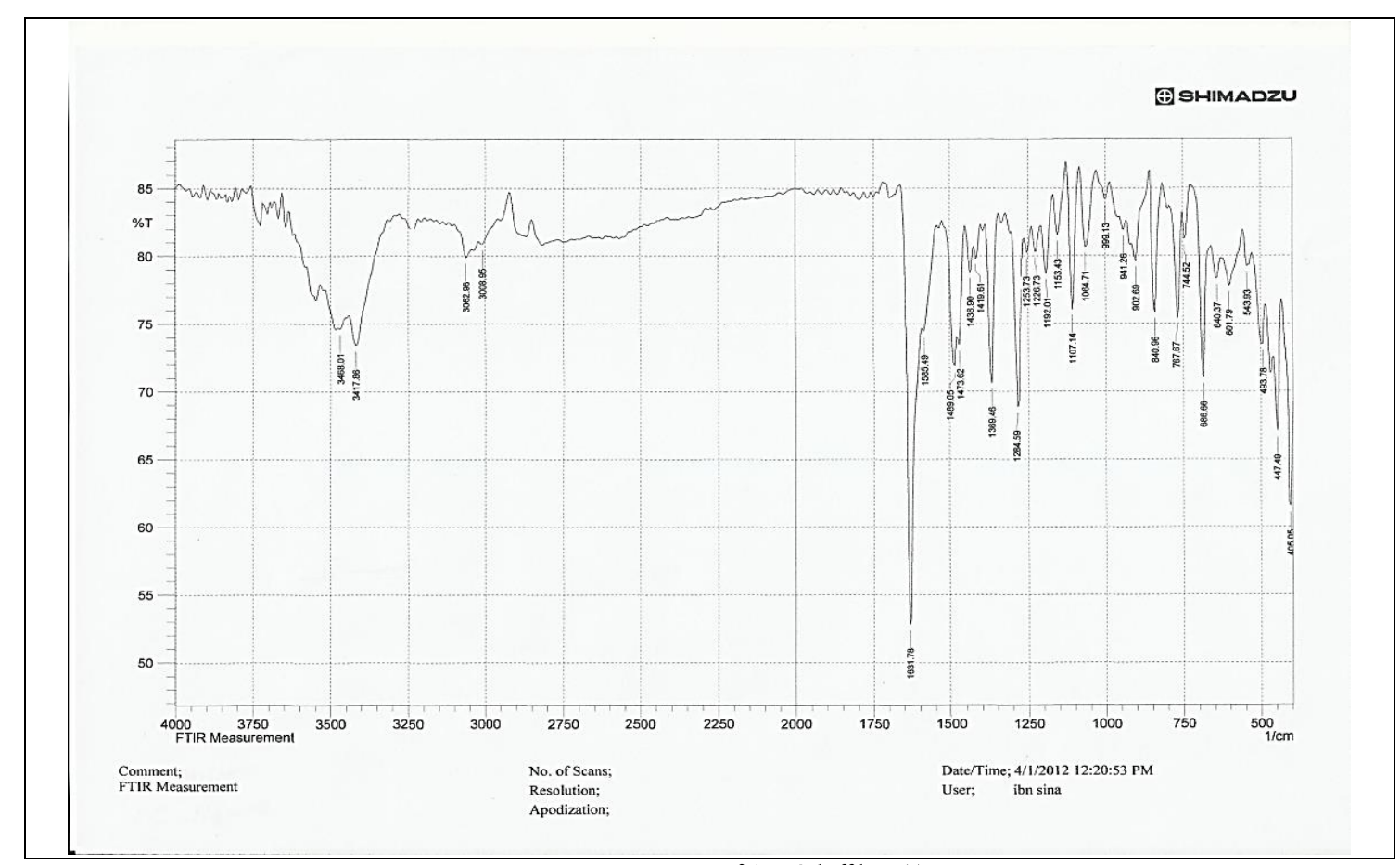

Fig.3. IR spectrum of Azo-Schiff base(I)

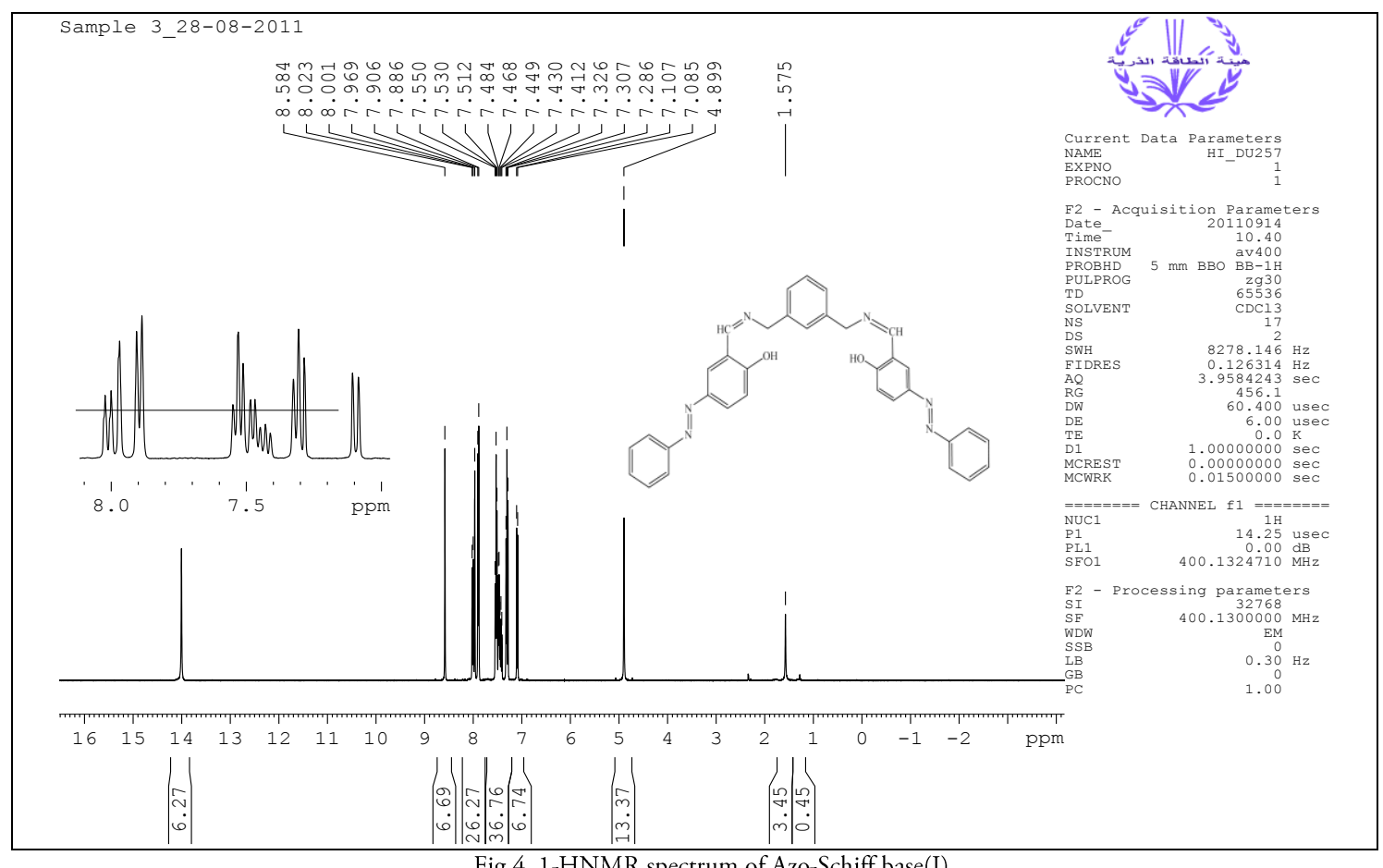

Fig.4. 1-HNMR spectrum of Azo-Schiff base(I) 
for 3 hour with continue stirrer. A solid mass formatted on hot. The reaction mixture was allowed to cool room temperature, it was suction filtered and recrystallized from suitable solvent, then dried in vacuum $[36,37]$.

Dark red; Yield: $(75 \%), \mathrm{m} . \mathrm{p}=206-209{ }^{\circ} \mathrm{C}$, Empirical formula: $\quad\left(\mathrm{C}_{31} \mathrm{H}_{23} \mathrm{~N}_{7} \mathrm{O}_{2}\right)$, M.Wt: 525

Mass spectrum (m/z):525 (Fig.5.).

UV-Vis: $\lambda \max =345 \mathrm{~nm}$ (Fig.6.).

IR (KBr disk): $3414.86-3475.73 \mathrm{~cm}^{-1}(\mathrm{O}-\mathrm{H})$, 3005.10-3059.10 $\mathrm{cm}^{-1} \quad(\mathrm{C}-\mathrm{H})$, aromatic), $1612.49 \mathrm{~cm}^{-1}(\mathrm{C}=\mathrm{N}), 1566.20 \mathrm{~cm}^{-1} \quad(\mathrm{C}=\mathrm{C}$, aromatic), $\quad 1485.19 \quad \mathrm{~cm}^{-1} \quad(\mathrm{~N}=\mathrm{N})$, $1280.73 \mathrm{~cm}^{-1}$ (C-O), phenolic) (Fig.7.).

1H-NMR $\left(\mathrm{CDCl}_{3}-400 \mathrm{MHz}\right) \delta=13.7(\mathrm{~s}, 2 \mathrm{H}$, $\mathrm{OH}), 8.089-6.995$ (m, $19 \mathrm{H}, \mathrm{Ar}), 8.809$ (s, $2 \mathrm{H}, \mathrm{CH}=\mathrm{N}$. (Fig.8.).

Elemental analysis: $\mathrm{C}_{31} \mathrm{H}_{23} \mathrm{~N}_{7} \mathrm{O}_{2}$, Calculated (\%): C: 70.84; H: 4.41; N: 18.66 Found(\%) C: 70.80, H:4.38, N:18.6.

\subsubsection{SYNTHESIS OF BIS-N-(5-PHENYLAZO-2- HYDROXY-1-BENZYLIDINE) - 1， 5-DIAMINO-2- METHYL PENTANE (III)}

Azo-coupled precursors were prepared as described previously [35] was added (0.01 mol) of 3-formyl-4-hydroxy phenylazo benzene in $30 \mathrm{ml}$ from absolute ethanol to 1,5-diamino-2-methyl pentane, $(0.005 \mathrm{~mol})$ in $60 \mathrm{ml}$ ethanol, The reaction mixture was refluxed for 3 hour with continue stirrer. A solid mass formatted on hot. The reaction mixture was allowed to cool room temperature; it was suction filtered Scheme (4) and recrystallized from suitable solvent, then dried in vacuum $[36,37]$.

Orange; Yield: $(78 \%), \mathrm{m} . \mathrm{p}=140-143{ }^{\circ} \mathrm{C}$, Empirical formula: $\left(\mathrm{C}_{32} \mathrm{H}_{32} \mathrm{~N}_{6} \mathrm{O}_{2}\right)$.M.Wt: 532 . Mass spectrum (m/z):532. (Figure 9)

UV-Vis: $\lambda \max =370 \mathrm{~nm}$ (Figure 10)

IR ( $\mathrm{KBr}$ disk): $3417.86-3475.73 \mathrm{~cm}^{-1}(\mathrm{O}-\mathrm{H})$, $3059.10 \mathrm{~cm}-1$ (C-H, aromatic), 2812.21-
$2935.66 \mathrm{~cm}^{-1}$ (C-H, aliphatic), $1635.64 \mathrm{~cm}^{-1}$ $(\mathrm{C}=\mathrm{N}), \quad 1585.49 \mathrm{~cm}^{-1} \quad(\mathrm{C}=\mathrm{C}, \quad$ aromatic $)$, $1496.76 \mathrm{~cm}^{-1}(-\mathrm{N}=\mathrm{N}-), 1284.59 \mathrm{~cm}^{-1}$ (C-O, phenolic) (Fig.11.).

$1 \mathrm{H}-\mathrm{NMR}\left(\mathrm{CDCl}_{3}-400 \mathrm{MHz}\right) \delta=14.318(\mathrm{~d}$, $2 \mathrm{H}, \quad \mathrm{OH}), \quad 8.438-8.458(\mathrm{~d}, \quad 2 \mathrm{H}, \mathrm{CH}=\mathrm{N})$, $7.080-8.012(\mathrm{~m}, 16 \mathrm{H}, \mathrm{Ar}), 3.510-3.685$ $(\mathrm{t}, 4 \mathrm{H}-\mathrm{CH} 2-\mathrm{N}=), 1.375-1.974 \quad\left(\mathrm{~m}, 4 \mathrm{H},-\mathrm{CH}_{2}-\right)$,

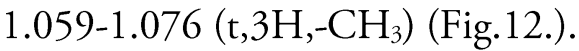

Elemental analysis: $\mathrm{C}_{31} \mathrm{H}_{23} \mathrm{~N}_{7} \mathrm{O}_{2}$, Calculated (\%) C: 72.16; H: 6.01; N: 15.78. Found (\%) C: 72.17, H: 5.91, N: 15.63.

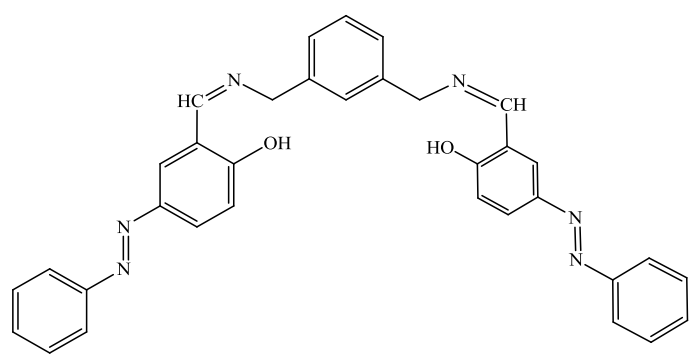

Scheme 2 Azo Schiff base(I)
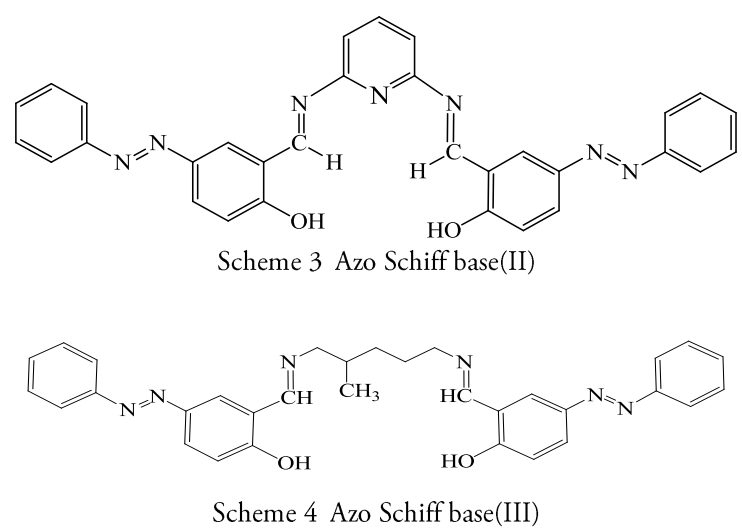

\subsection{BIOLOGICAL ACTIVITY}

The prepared compounds were tested for their antimicrobial activity against four species of bacteria (Bacillus subtilis, Escherichia coli, Staphylococcus aureus, Salmonella typhi) using filter paper disc method [38]. The screened compounds were dissolved individually in DMSO (dimethyl sulfoxide) in order to make up a solution of 50,100 , and $200 \mu \mathrm{g} / \mathrm{ml}$ concentration for each of these 


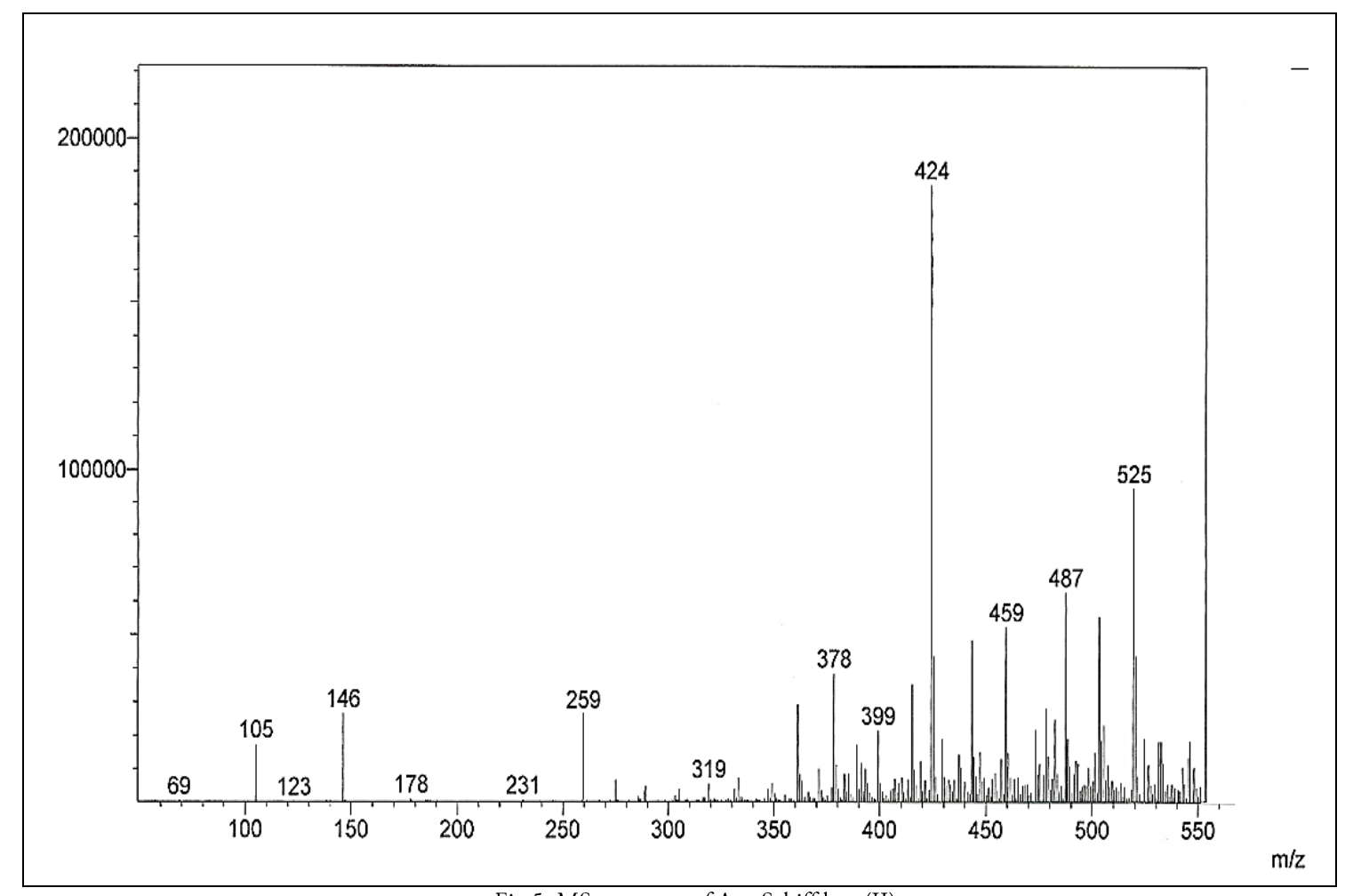

Fig.5. MS spectrum of Azo-Schiff base(II)

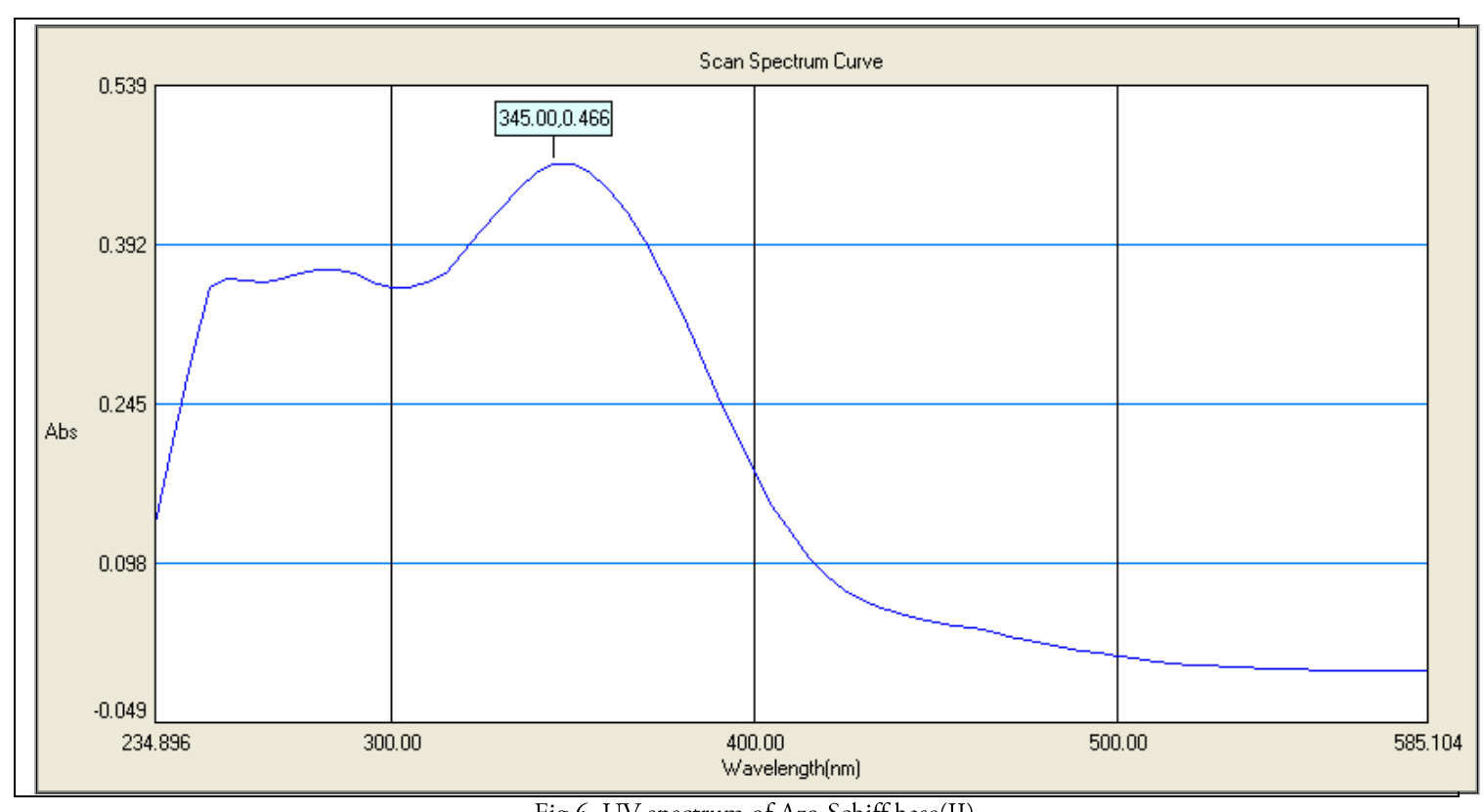

Fig.6. UV spectrum of Azo Schiff base(II) 


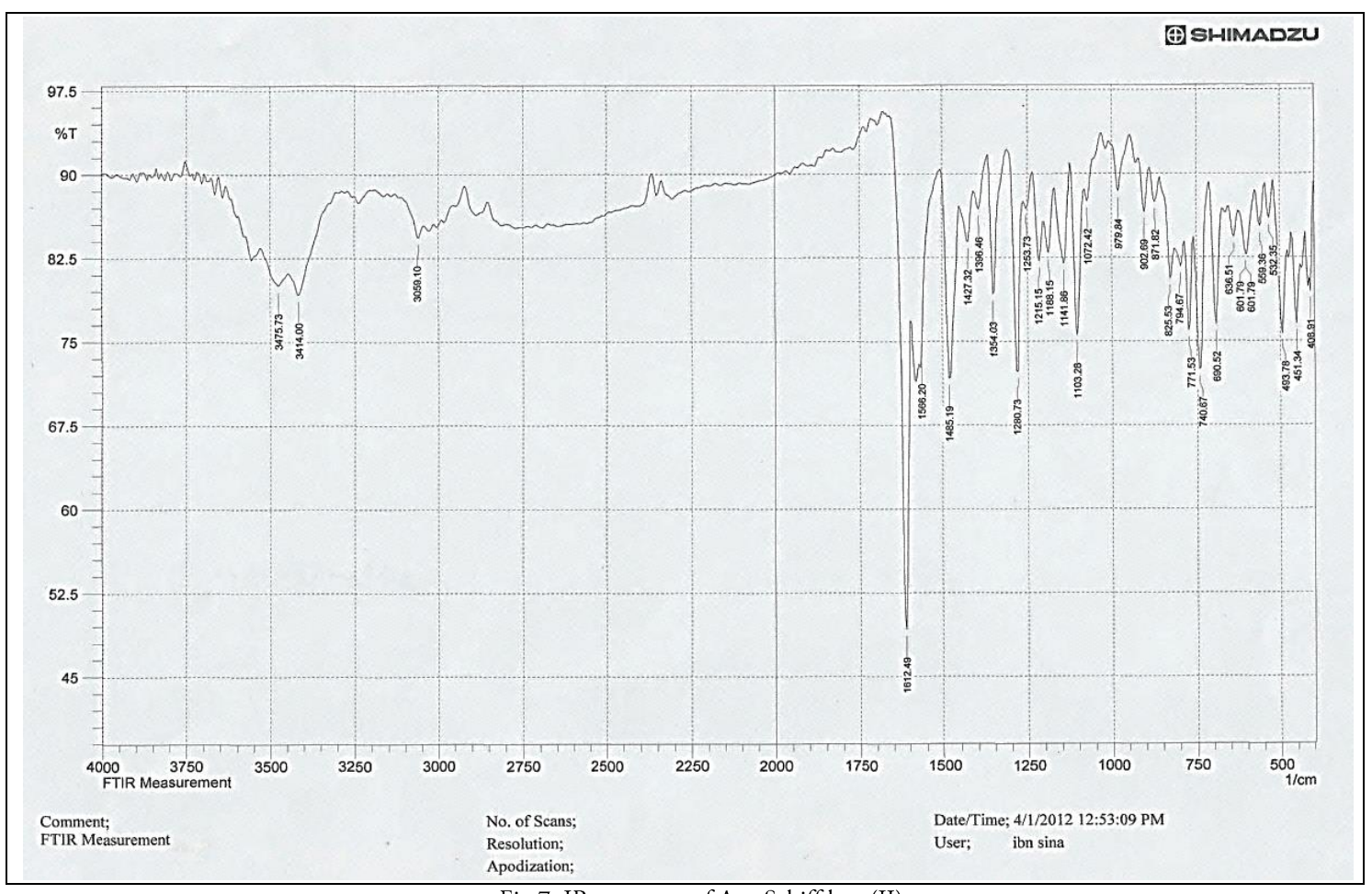

Fig.7. IR spectrum of Azo-Schiff base(II)

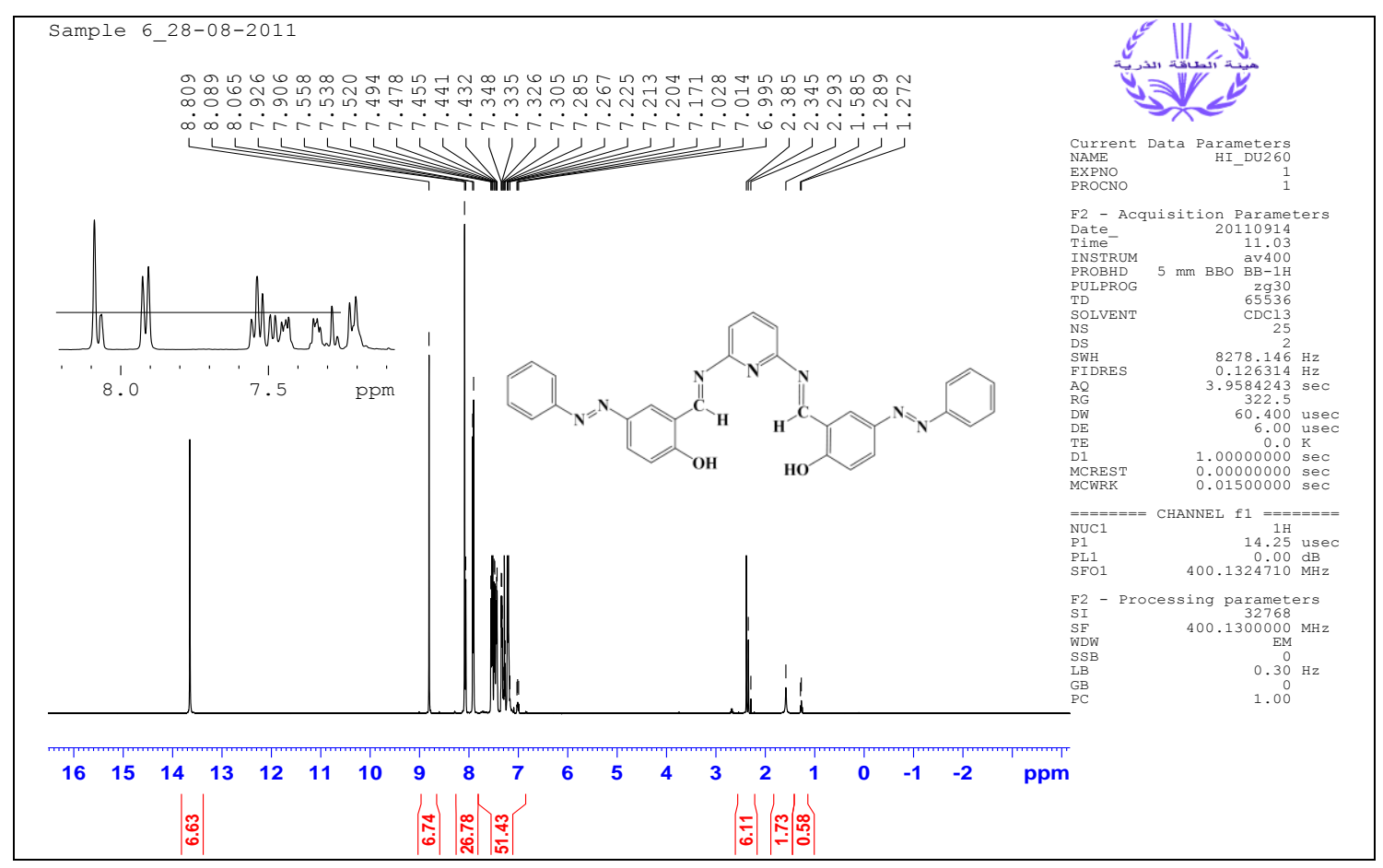

Fig.8. 1-HNMR spectrum of Azo-Schiff base(II) 


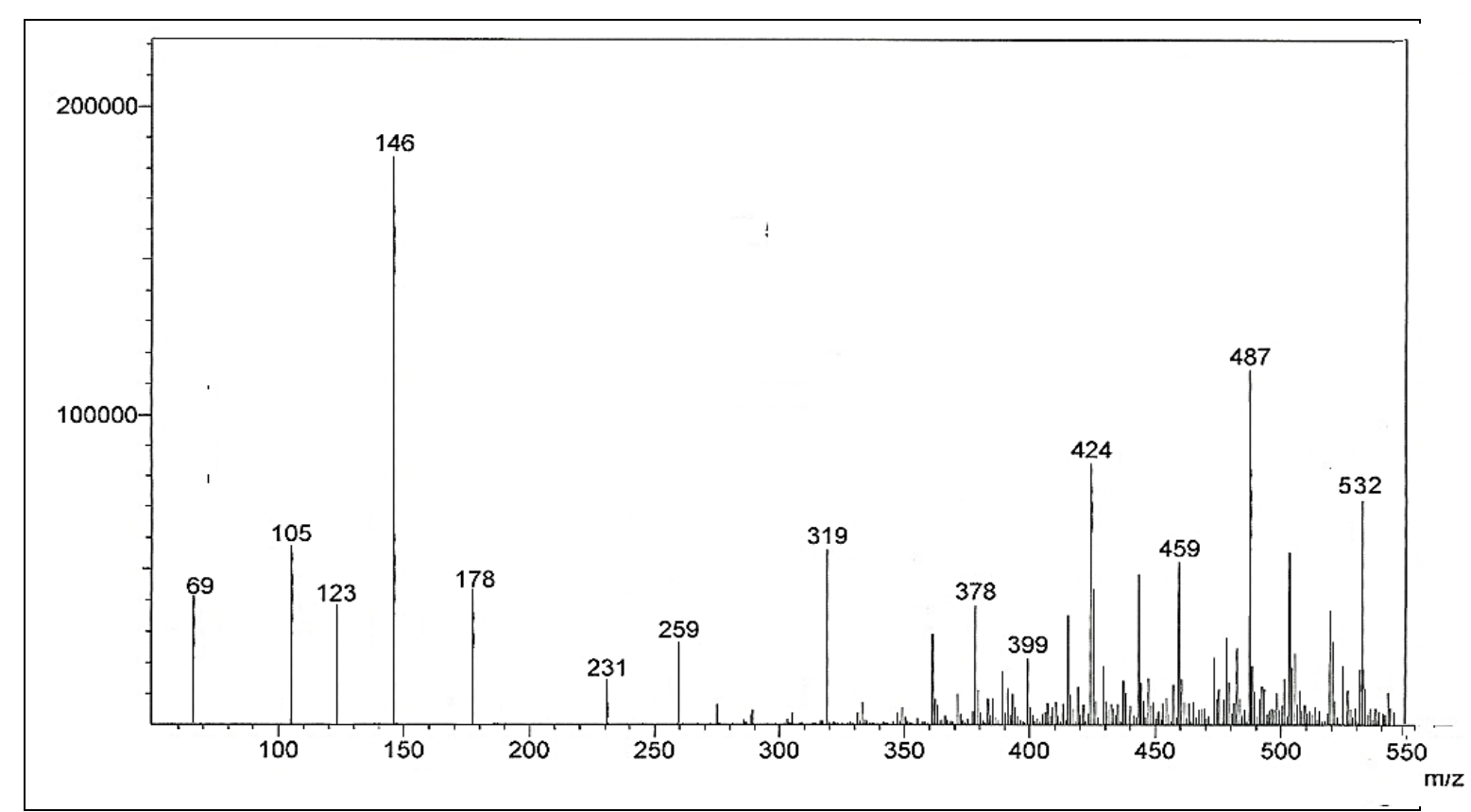

Fig.9. MS spectrum of Azo-Schiff base(III)

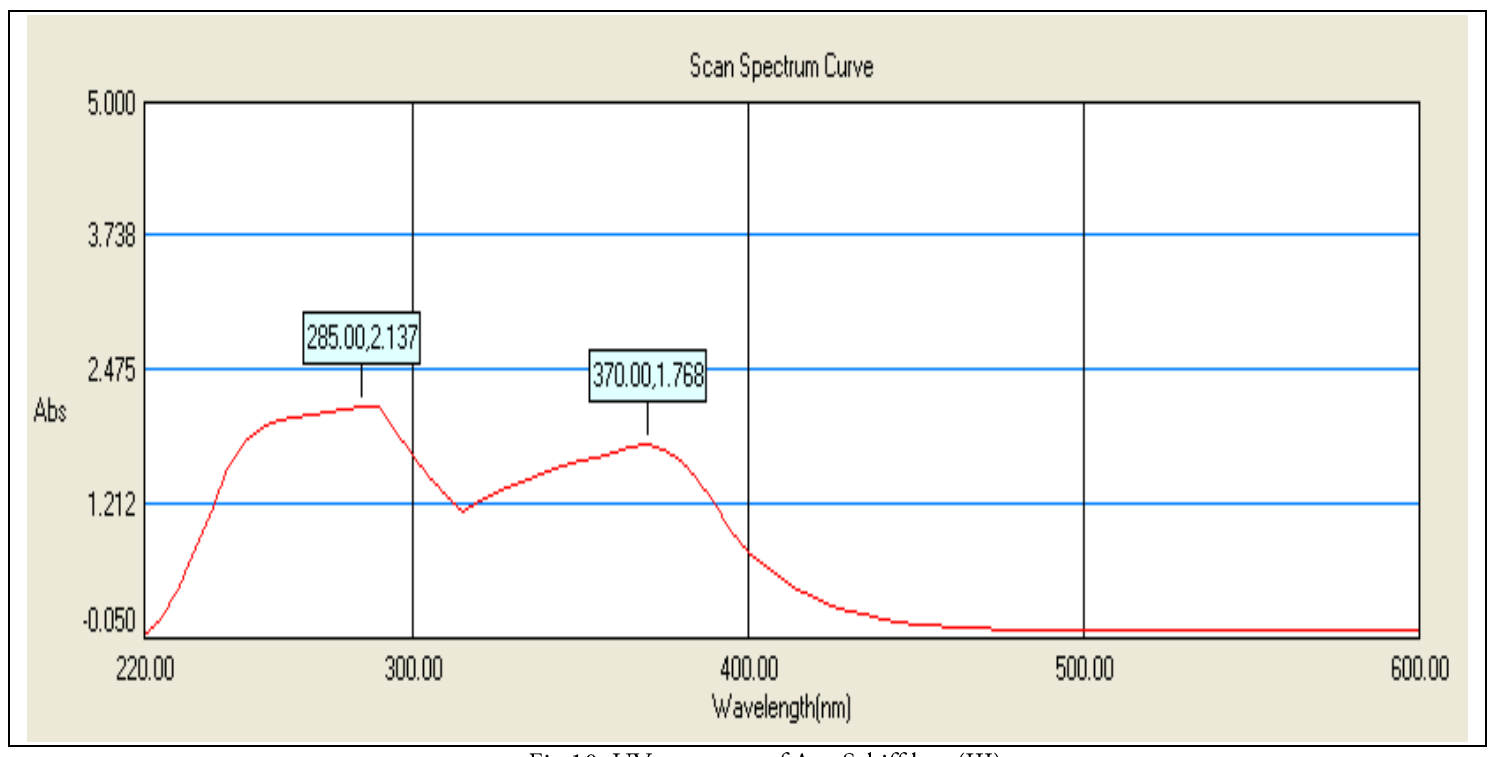

Fig.10. UV spectrum of Azo Schiff base(III) 


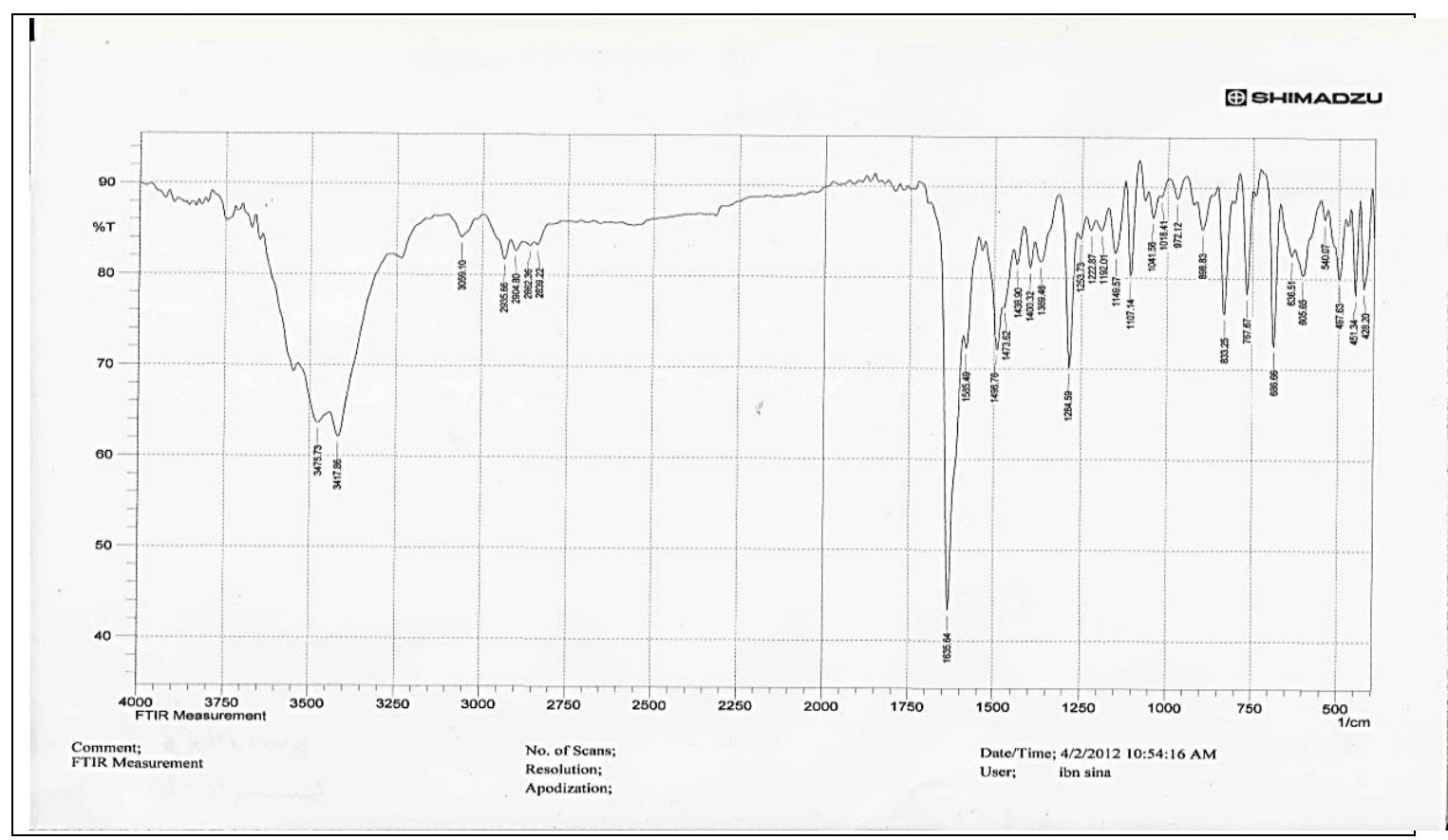

Fig.11. IR spectrum of Azo-Schiff base(III)

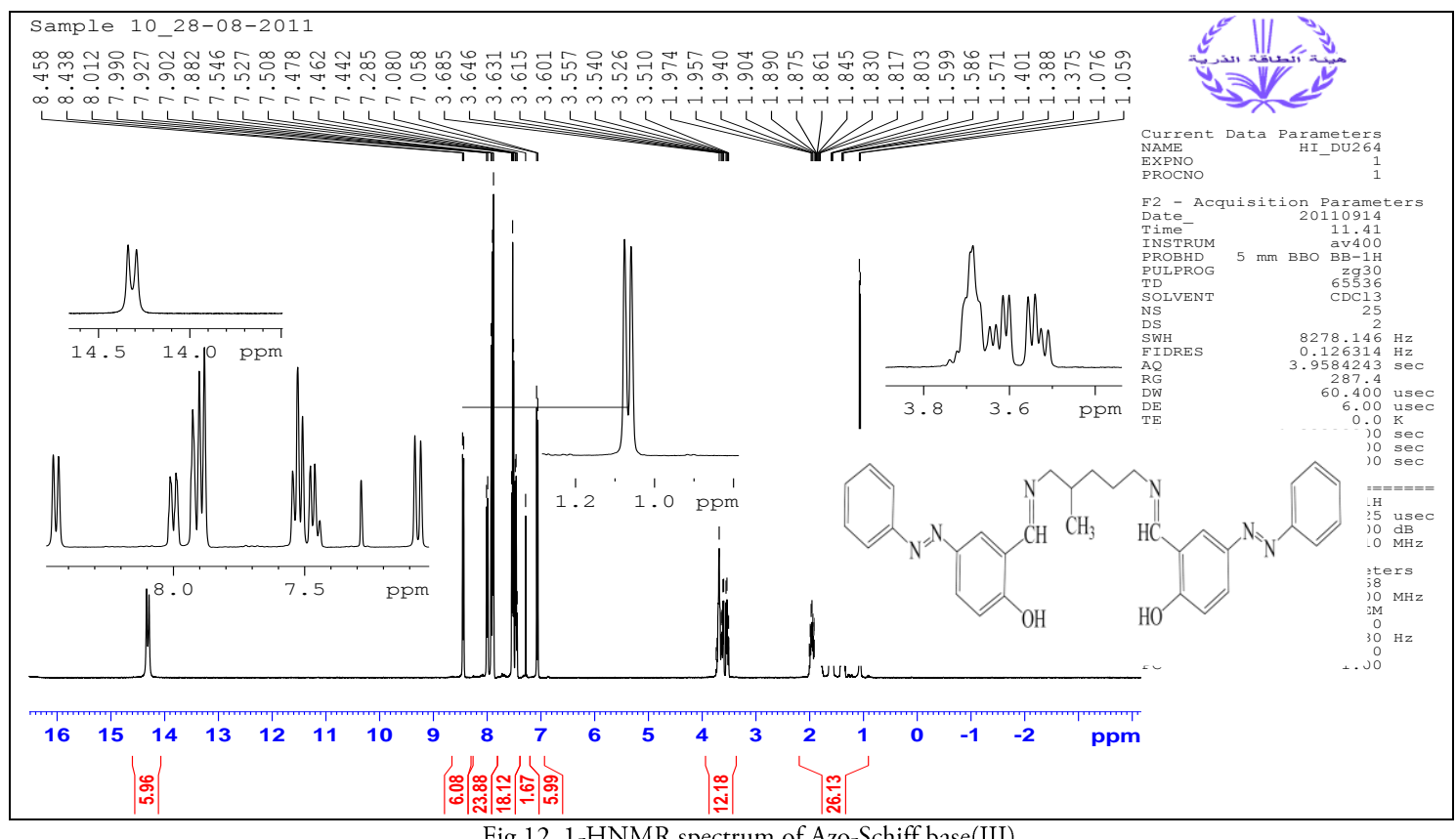

Fig.12. 1-HNMR spectrum of Azo-Schiff base(III) 
TABLE 1: COLOUR, MOLECULAR WEIGHT, MELTING POINT OF (I, II, III).

\begin{tabular}{|c|c|c|c|c|c|c|}
\hline $\begin{array}{c}\text { Azo Shiff } \\
\text { base }\end{array}$ & Color & M.Wt & Melting point ${ }^{\mathbf{0}} \mathbf{C}$ & $\begin{array}{c}\boldsymbol{\lambda}_{\max } \\
\mathbf{n m}\end{array}$ & $\begin{array}{c}\text { Yield } \\
\mathbf{\%}\end{array}$ & $\begin{array}{c}\text { Crystallization } \\
\text { Solvent }\end{array}$ \\
\hline I & Orange & 552 & $189.3-189.6$ & 355 & 80 & Toluene or DMF \\
\hline II & Dark red & 525 & $206-209$ & 345 & 75 & Toluene or p-Xylene \\
\hline III & Yellow & 532 & $140-143$ & 370 & 78 & Dioxan \\
\hline
\end{tabular}

TABLE 2: ELEMENTAL ANALYSIS DATA OF AZO SCHIFF BASES (I, II, III)

\begin{tabular}{|c|c|c|c|}
\hline \multirow{2}{*}{$\begin{array}{c}\text { Azo Shiff } \\
\text { base }\end{array}$} & \multicolumn{3}{|c|}{$\begin{array}{c}\text { Elemental analysis } \\
\text { Calculated (Found \%) }\end{array}$} \\
\cline { 2 - 4 } & $\mathrm{C}$ & $\mathrm{H}$ & $\mathrm{H}$ \\
\hline \multirow{2}{*}{ I } & $\begin{array}{c}73.97 \\
(73.90)\end{array}$ & $\begin{array}{c}5.17 \\
(5.11)\end{array}$ & $\begin{array}{c}15.18 \\
(15.21)\end{array}$ \\
\hline II & 70.80 & 4.38 & 18.67 \\
& $(70.84)$ & $(4.41)$ & $(18.66)$ \\
\hline III & 72.17 & 5.91 & 15.63 \\
& $(72.16)$ & $(6.01)$ & $(15.78)$ \\
\hline
\end{tabular}

compounds. Filter paper discs (Whitman No.1 filter paper, $5 \mathrm{~mm}$ diameter) were saturated with the solution of these compounds. The discs were placed on the surface of solidified Nutrient agar dishes seeded by the tested bacteria. The diameters of inhibition zones $(\mathrm{mm})$ were measured at the end of an incubation period, which was $24 \mathrm{~h}$ at $37^{\circ} \mathrm{C}$ for bacteria. Discs saturated with DMSO are used as solvent control. Ciprofloxacin $100 \mu \mathrm{g} / \mathrm{ml}$ was used as reference substance for bacteria [38].

\section{RESULTS AND DISCUSSION}

\subsection{SYNTHESIS}

The reactions proceeded smoothly, producing the corresponding Azo Schiff bases in good yield. The Schiff bases were checked by different spectral technique (LC-MS, GC-MS, $1 \mathrm{H}-\mathrm{NMR}$, IR) which helps in elucidating their empirical formula (Table 1).

\subsection{ELEMENTAL ANALYSES OF AZO SCHIFF BASES}

The results of elemental analyses of Azo Schiff bases are shown in Table 2 .

\subsection{IR SPECTRA}

The IR Spectral data are shown in Table 3 of the prepared azo schiff bases. The three bands at $1631.78,1612.49$ and $1635.64 \mathrm{~cm}^{-1}$ are attributed to imine group (-HC=N-) for (I, II, III) (Figures 3, 7, 11), respectively. The bands in the spectra at $1585.49,1566.20$ and $1585.49 \mathrm{~cm}^{-1}$ are due to $(\mathrm{C}=\mathrm{C})$ of aromatic rings. The $\mathrm{v}(\mathrm{OH})$ stretching frequencies bands are observed at 3417.86 - 3468.01, $3414.86-3475.73$ and $3417.86-3475.7 \mathrm{~cm}^{-}$ 1 for (I,II,III), respectively. The IR spectra of (I, II, III) shows characteristic absorption bands at $1473.62-1489.05,1485.19$ and $1496.76 \mathrm{~cm}^{-1}$ due to $v(\mathrm{~N}=\mathrm{N})$ stretching vibrations respectively. The bands which observed for all compounds at 1284.59, 1280.73 and $1284.5 \mathrm{~cm}^{-1}$ are due to $v(\mathrm{C}-\mathrm{O})$ vibration. 
TABLE 3: IR SPECTRAL DATA $\left(\mathrm{cm}^{-1}\right)$ OF AZO SCHIFF BASES (I, II, III)

\begin{tabular}{|c|c|c|c|c|c|c|c|}
\hline $\begin{array}{c}\text { Azo Shiff } \\
\text { base }\end{array}$ & $\begin{array}{c}\boldsymbol{v}(\mathrm{C}-\mathrm{O}) \\
\mathbf{c m}^{-1}\end{array}$ & $\begin{array}{c}\boldsymbol{v}(\mathrm{N}=\mathrm{N}) \\
\mathbf{c m}^{-1}\end{array}$ & $\begin{array}{c}\boldsymbol{v}(\mathrm{C}=\mathrm{C}) \\
\mathbf{c m}^{-1}\end{array}$ & $\begin{array}{c}\boldsymbol{v}(\mathrm{C}=\mathbf{N}) \\
\mathbf{c m}^{-1}\end{array}$ & $\begin{array}{c}\boldsymbol{v}(\mathrm{C}-\mathrm{H}) \\
\mathbf{a l i p h}\end{array}$ & $\begin{array}{c}\boldsymbol{v}(\mathrm{C}-\mathrm{H}) \mathbf{a r o m} . \\
\mathbf{c m}^{-1}\end{array}$ & $\begin{array}{c}\boldsymbol{v}(\mathrm{OH}) \\
\mathbf{c m}^{-1}\end{array}$ \\
\hline I & 1284.59 & $\begin{array}{c}1473.62- \\
1489.05\end{array}$ & 1585.49 & 1631.78 & 2881.65 & $3008.95-3062.96$ & $\begin{array}{c}3417.86- \\
3468.01\end{array}$ \\
\hline II & 1280.73 & 1485.19 & 1566.20 & 1612.49 & ------ & $3005.10-3059.10$ & $\begin{array}{c}3414.86- \\
3475.73\end{array}$ \\
\hline III & 1284.59 & 1496.76 & 1585.49 & 1635.64 & $\begin{array}{c}2839.2- \\
2935.7\end{array}$ & 3059.10 & $\begin{array}{c}3417.86- \\
3475.73\end{array}$ \\
\hline
\end{tabular}

TABLE 4: 1H-NMR SPECTRA OF OF AZO SCHIFF BASES (I, II, III)

\begin{tabular}{|c|c|c|c|}
\hline \multirow{2}{*}{ Azo Shiff base } & \multicolumn{3}{|c|}{ Chemical Shifts $\quad \boldsymbol{\delta} \mathbf{~ p p m}$} \\
\cline { 2 - 4 } & OH & CH=N & $\begin{array}{c}\text { C-H } \\
\text { Aromatic }\end{array}$ \\
\hline \multirow{2}{*}{ I } & $\begin{array}{c}14 \\
(s, 2 \mathrm{H})\end{array}$ & $\begin{array}{c}8.584 \\
(\mathrm{~s}, 2 \mathrm{H})\end{array}$ & $\begin{array}{c}8.023-7.085 \\
(\mathrm{~m}, 20 \mathrm{H})\end{array}$ \\
\hline II & $\begin{array}{c}13.7 \\
(\mathrm{~s}, 2 \mathrm{H})\end{array}$ & $\begin{array}{c}8.809 \\
(\mathrm{~s}, 2 \mathrm{H})\end{array}$ & $8.089-6.995(\mathrm{~m}, 19 \mathrm{H})$ \\
\hline III & 14.318 & $8.438-8.458(\mathrm{~d}, 2 \mathrm{H})$ & $\begin{array}{c}8.023-7.085 \\
(\mathrm{~m}, 16 \mathrm{H})\end{array}$ \\
\hline
\end{tabular}

while the bands at 2881.65 and 2839.2$2935.7 \mathrm{~cm}^{-1}$ are attributed to (C-H alkanes) for(I, II, III) respectively. Also, the bands at $3417.86-3468.01, \quad 3414.86-3475.73$ and $3417.86-3475.73 \mathrm{~cm}^{-1}$ are attributed to (C$\mathrm{H}$ Ar) for (I, II,III) respectively. However, in the IR spectra of azo schiff bases this band $(\mathrm{C}=\mathrm{O})$ disappeared and a new vibration band for azo methane $(-\mathrm{HC}=\mathrm{N}-)$ is observed at 1631.78, 1612.49 and $1635.64 \mathrm{~cm}^{-1}$ indicating that complete condensation took place[39-40].

\subsection{H-NMR SPECTRA OF LIGANDS (I, II,III)}

The data of ${ }^{1} \mathrm{H}-\mathrm{NMR}$ Spectra of prepared azo Schiff bases are shown in Table 4. The ${ }^{1} \mathrm{HNMR}$ spectra of ( I, II, III) ligands in d6DMSO (Figures 4, 8, 12) shows a singlet signal at $14,13.7 \mathrm{ppm}$ assigned to the protons $\mathrm{OH}$ groups of the Ligands (I, II) respectively. The doublet signals $14.318 \mathrm{ppm}$ assigned to the protons $\mathrm{OH}$ group of the ligand (III). The multiple signals $8.023-7.085,8.089$ $6.995,8.023-7.085 \mathrm{ppm}$ are due to the aromatic protons for (I, II, III) respectively. The doublet signals at $8.438-8.458 \mathrm{ppm}$ are due to the $2 \mathrm{H},(\mathrm{HC}=\mathrm{N})$ protons of the ligand (III), while the signals at $8.584,8.809 \mathrm{ppm}$ are assigned to the $2 \mathrm{H},(\mathrm{HC}=\mathrm{N})$ protons of the ligands (I, II), respectively. The other obtained values for ${ }^{1} \mathrm{H}-\mathrm{NMR}$ chemical shifts of these compounds are given in the experimental section. These data are in agreement with those previously reported for similar compounds [39]. These results strongly suggest that the proposed compounds have been formed [40].

\subsection{BIOLOGICAL ACTIVITY}

During the last two or three decades, attention has been increasingly paid to the synthesis of Azo Schiff bases which exhibits 
TABLE 5: EFFECT OF NEW AZO SCHIFF BASES ON THE GROWTH OF TESTED BACTERIA (CONC. 200 MG/ML)

\begin{tabular}{|c|rr|rr|rrr|rc|}
\hline \multirow{2}{*}{ Azo Shiff base } & \multicolumn{8}{|c|}{ Bacteria } \\
\cline { 2 - 9 } & \multicolumn{6}{|c|}{ Gram negative } & \multicolumn{4}{c|}{ Gram positive } \\
\cline { 2 - 9 } & \multicolumn{2}{|c|}{ B. subtilis } & \multicolumn{2}{|c|}{ S. aureus } & \multicolumn{2}{|c|}{ E.coli } & \multicolumn{2}{c|}{ S. typhi } \\
\hline I & 14 & $\mathrm{~mm}$ & 11 & $\mathrm{~mm}$ & 10 & $\mathrm{~mm}$ & 12 & $\mathrm{~mm}$ \\
\hline II & 18 & $\mathrm{~mm}$ & 15 & $\mathrm{~mm}$ & 14 & $\mathrm{~mm}$ & 16 & $\mathrm{~mm}$ \\
\hline IV & 10 & $\mathrm{~mm}$ & 12 & $\mathrm{~mm}$ & 17 & $\mathrm{~mm}$ & 16 & $\mathrm{~mm}$ \\
\hline Control & 00 & $\mathrm{~mm}$ & 00 & $\mathrm{~mm}$ & 00 & $\mathrm{~mm}$ & 00 & $\mathrm{~mm}$ \\
\hline Ciprofloxacin & 20 & $\mathrm{~mm}$ & 20 & $\mathrm{~mm}$ & 20 & $\mathrm{~mm}$ & 20 & $\mathrm{~mm}$ \\
\hline
\end{tabular}

various biological activities including antibacterial, fungicidal, tuberculostatic and plant growth regulative properties [41]. It was judicious to investigate the synthesis of various new types of Azo Schiff bases and studied their antibacterial activity against four strains of bacteria (Bacillus subtilis, Escherichia coli, Staphylococcus aureus, Salmonella typhi).

The concentrations used for the screened compounds are 50, 100, and $200 \mu \mathrm{g} / \mathrm{ml}$. Ciprofloxacin was used as reference standard while DMSO as control and inhibition zones is measured in $\mathrm{mm}$. The new compounds have been tested against a series of bacteria nurs. The test results are presented in Fig.13, where some new compounds were active against tested and other compounds were not active.

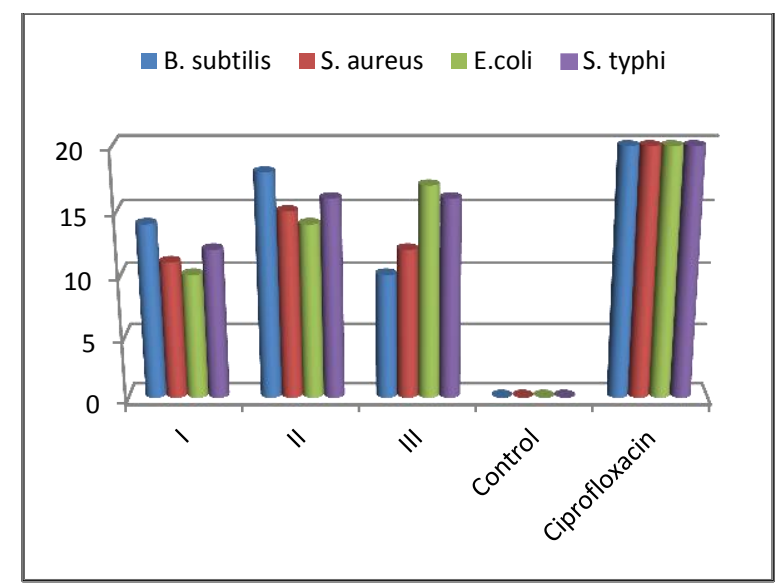

Fig.13. Antibacterial activity (Gram positive, negative) of synthesized compounds
All compounds are not active when using 50, and $100 \mu \mathrm{g} / \mathrm{ml}$ but active in the concentrations of $200 \mu \mathrm{g} / \mathrm{ml}$ as seen in Table 5.

\section{CONCLUSION}

1- The (I, II, III) compounds are new and were prepared for the first time.

2- The new compounds were identified by ${ }^{1}$ HNMR, IR, and LC-MS spectral methods. 3-Some of the prepared compounds have been biologically screened i.e. studying their effects against two gram-positive, two gramnegative bacteria. The results show that their activities were found to vary from moderate to very strong.

\section{ACKNOWLEDGMENT}

The author is grateful to the Department of Chemistry, Faculty of Science, University of Damascus, Damascus, Syria for supporting of this paper.

\section{REFERENCES}

[1] Pandey, V.K., and Negi, H.S., "Synthesis and Antimicrobial Activity of Some New Formazan Derivatives". Indian Drugs, 36(1), 37, 1999.

[2] Morrison and Boyed, "Organic Chemistry", 6th Ed., 1996.

[3] Cimerman, Z., Milijanic, S., and Galic, N., "Schiff Bases Derived from Amino Pyridines as Spectroflourimetric Analytical Reagents". Croatica Chemica Acta, 73(1), 81-95, 2000. 
[4] Venturini, A., and Gonzalez, J., "Staudinger Reduction", J. Org. Chem., 67, 9089-9092, 2002.

[5] RAMAN, N., Pitchaikani, Y., and Kulandaisamy, A., "Synthesis and Characterization of $\mathrm{cu}(\mathrm{II})$, $\mathrm{Ni}(\mathrm{II}), \mathrm{Zn}(\mathrm{II})$ and $\mathrm{VO}(\mathrm{II})$ Schiff base complexes derived from ophenylene diamine and acetoactanilide". Proc. Indian Acad. Sci., 113(3), 183-189, 2001.

[6] Garg, H.G., and Kauv, M.S., "Synthesis of benzyaldehyde substituted phenyl carbonyl hydrazones”. J. Med. Chem., 15, 554, 1992.

[7] Sharma, K.P., Jolly, V.S., Phatak, P., "Schiff bases and their derivatives as potential anticancer agents", Ultra Scient. Phys. Sci., 10, 263-266, 1998.

[8] Jarrahpour, A.A., and Zarei, M., "Synthesis of (3,4-bis\{[2-hydroxy-3-methoxy- -(4methylphenylazo) benzylidene]-amino\}penyl) phenyl methanone as a novel azo Schiff base". Molnank, M 376, 1-3, 2004.

[9] Muhammed, I., Javed, I., Shahid, I., and Nazia, I., "In Vitro Antibacterial Studies of Ciprofloxacinimines and their Complexes with $\mathrm{Cu}(\mathrm{II}), \mathrm{Ni}(\mathrm{II})$, Co(II) and Zn(II)". Turk. J. Biol., 31, 67-72, 2007.

[10] Vashi, K., and Naik, H.B. "Synthesis of Novel Schiff base and Azetidinone Derivatives and Their Antibacterial Activity". Eur. J. Chem., (1), 272-276, 2004.

[11] Mone, P., Bhalvankar, R., and Pattar, S., "Synthesis of Some Iimes and Investigation of Their Biological Activity". J. Indian Chem., 78, 474-475, 2001.

[12] Vaghasiya, Y.K., Nairi, R.S., Baluja, M., Chonda, S.S., "Synthesis, Structural Determination and Antibacterial Activity of Compounds Derived From Vasaillin and 4-Amino antipyrine". J. Scrt. Chem. Soc., 69, 991-998, 2004.

[13] Mtrei, R., Yadawe, M., and Patil, S.A., "Synthesis of Biological Active p-bis(amino-5-mercapto1,2,4-triazole-3-yl)benzene and its Schiff base: a new class of bistriazole". Orient. J. Chem., (12), 101-102, 1996.

[14] Hussain, M.E., Allam, M.V., Begum, J. Akbar, M.A., Hddin, M.N., Smith, F.E., and Hynes, R.C., "The Preparation, Characterization, Crystal and Biological Activities of Some $\mathrm{Cu}(\mathrm{II})$ Complexes of the 2-benzoyl pyridine Schiff bases of 5-methyl and 5-benzyldithio carbazate". Inorg. Chem. Acta., 249, 207-213, 1996.
[15] Phatok, P., Jolly, V.S., and Sharma, K.P., "Synthesis and Biological Activities of Some New Substituted anyl azo Schiff base". Orient. J. Chem., 16, 493-494, 2000.

[16] Olcay, B., and Hakan, B., "Synthesis of Schiff and Mannich Bases of Isatin Deivatives with 4Amino-4,5-Dihydro-1H-1,2,4-Triazole-5- Cues". Molecules, 13, 2126-2135, 2008.

[17] Pandeya, S.N., Sriram, D., Declercq,E., and Nath, G. "Synthesis, antibacterial, antifungal and antiHIV activities of Schiff and Mannich bases derived from isatin derivatives and (N-[4-(4)Chloro phenyl)thiazol-2-yl] thiosemicarbazide".Eur. J. Pharm. Sci., (9), 25-31, 1991.

[18] Jarraphour, A., and Zare, M."Synthesis of novel azo Schiff base bis[5-(4-methoxyphenylazo)-2hudroxy-3-methoxy benzaldehde]-1,2-phenylene diamine". Molbank,M 377, 1-3 2004.

[19] Jarraphour, A., Motamedifar, M., Pakshir, K., Hadi, N., and Zarei,M., "Synthesis of Novel Azo Schiff Bases and Their ntibacterial and Antifungal Activites". Molecules,9, 815-824, 2004.

[20] Nejati K, Rezvani Z, Massoumi B. Syntheses and investigation of thermal properties of copper complexes with azo-containing Schiff-base dyes. Dyesand Pigments,75(3):653-7, 2007.

[21] H. Rolla and O. Mermut, J. Pure Appl. Chem. , 76, 1445, 2004.

[22] Iranpoor, N., Firouzabadi, H., Khalili, D. \&Motevalli, S. . Easily prepared azopyridines as potent and recyclable reagents for facile esterification reactions: an efficient modified Mitsunobu reaction. J. Org. Chem., 73, 48824887, 2008.

[23] Antonov, L. M., Kurteva, V. B., Simeonov, S. P.,Deneva, V. V., Crochet, A. \& Fromm, K. M. .Tautocrowns: a concept for a sensing molecule withan active side-arm. Tetrahedron, 66, 4292-4297, 2010.

[24] Park, J. \& Koh, J. (2009). The synthesis and spectral properties of an encapsulated aminoazobenzene dye. Dyes Pigm., 82, 347-352.

[25] Zollinger, H.. Diazo Chemistry I, VCH, Weinheim, 1994.

[26] Ylldiz, E. \& Boztepe, H.. Synthesis of Novel Acidic Mono Azo Dyes and an Investigation of Their Use in the Textile Industry. Turk. J. Chem., 26, 897-903, 2002. 
[27] Jarrahpour, A. \& Alvand, P.. Synthesis of some new sugar based 3,3-disubstituted monocyclic _lactams by asymmetric $[2+2]$ cycloaddition reactions. Iran. J. Sci. Technol. Trans. A-Sci. 31, 17-22, 2007.

[28] Jarrahpour, A. \& Zarei, M.. Efficient onepot synthesis of 2-azetidinones from acetic acid derivatives and imines using methoxymethyleneN,N-dimethyliminium salt. Tetrahedron, 66, 5017- 5023, 2010.

[29] Jarrahpour, A. \& Zarei, M.. DMF-dimethyl sulfate as a new reagent for the synthesis of $S$ lactams. Tetrahedron Lett., 50, 1568-1570, 2009.

[30] Zarei, M. \& Mohamadzadeh, M. . 3- Thiolated 2-azetidinones: synthesis and in vitro antibacterial and antifungal activities. Tetrahedron, 67, 58325840, 2011.

[31] Jarrahpour, A. \& Zarei, M. . The Vilsmeier reagent: a useful and versatile reagent for the synthesis of 2-azetidinones. Tetrahedron, 65, 2927-2934, 2009.

[32] A. S. Zidan, A. I. El-Said, M. S. El-Meligy, A. A. Aly and O. F. Mohammed, J. Therm. Anal., 62, 665, 2000.

[33] M. F. Abo El-Ghar, N. T. Abdel-Ghani, Y. Badr and O. M. El-Borady, Science and Technology Vision, 3, 58, 2007.

[34] H. H. M. Al-Hmedawi, "Synthesis and Characterization of Transition Metal Chelates of Schiff-bases Derivatives of Expected Biological Activity", M.Sc. Thesis, The University of Baghdad, 2003.

[35] [56] Jarrahpour, A. A., Motamedifar, M., Pakshir, K., Hadi, N. \& Zarei, M. . Synthesis of novel azo Schiff bases and their antibacterial and antifungal activities. Molecules, 9, 815-824, 2004.

[36] Dinçaple H, Toker F, Durucasu I, Avcibas s, Icli S. New thiophene-based azo ligands containing azo methine group in the main chain for the determination of copper(II) ions. Dyes $\mathrm{Pi}$, 75:11e24, 2007.

[37] Khanmohammadi H, Darvishpour M. New azo ligands containing azomethine groups in the pyridazine-based chain: synthesis and characterization. Dyes Pigm 81:167e73, 2009.

[38] Ibrahim.U.H.,Basaran.I.,Kilic.T.,Cakir. U., Synthesis, complexation and anti- fungal, antibacterial activity studies of a new Macrocyclic Schiff Base ,J. Hetrocyclic Chem.,43,1679, 2006.
[39] Pathak, P., Jolly, V. S. \& Sharma, K. P..Synthesis and biological activities of some new substituted arylazo Schiff bases. Orient. J. Chem., 16, 161162, 2000.

[40] Rajaa, A.G., "Preparation of Some New AzoSchiff Bases Compounds and Studing Their Biological Activity". M.Sc. Thesis, College of education for Women, University of Kufa, 2008.

[41] Jarraphour, A., Motamedifar, M.,Pakshir, K., Hadi, N., and Zarei, M., "Synthesis of Novel Azo Schiff Bases and Their Antibacterial and Antifungal Activites". Molecules, 9, 815-824 2004. 


\title{
تحضير وتمييز قواعد أزوشيف جديدة ودراسة النشاط البيولوجي لها
}

\author{
حامد حسين عيسى \\ جامعة حجا ، اليمن
}

الملخص:

في هذا البحث نم التركيزعلى تحضير وتمييز بعض قواعد الأزو شيف والمحضرة من تكثيف

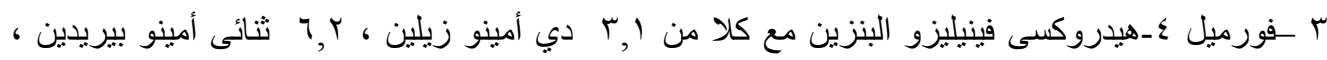

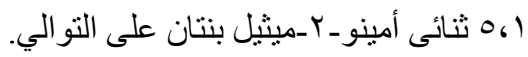

وتمت دراسة نثاط قو اعد الأزو شيف كمو اد مضاده (IR ،1H- NMR ،GC-MS ،LC-MS) باستخدام تقنية الأطياف للجر اثيم (العضوية الرقيقة والمكورات العنقودية الذهبية) و اثتبت الدراسة أنها موجبه الجرام و (السالمونيلا التيفية وكو لاي) هي سلبية الجر ام ـ أظهر البحث أن يجند الازو نشاطا متغير ا قادر ا على تثبيط ندو 